\title{
Isolation of Salmonella Typhimurium, Listeria monocytogenes and coagulase-positive Staphylococcus from salami sold at street fairs in Porto Alegre, Brazil
}

\author{
Isolamento de Salmonella Typhimurium, Listeria monocytogenes \\ e Staphylococcus coagulase positiva de salames comercializados \\ em feiras livres de Porto Alegre, Brasil
}

\author{
Gabriela Orosco Werlang1 (D), Louise Haubert ${ }^{2}$ (D), Cristina Mendes Peter ${ }^{2}$ (D), Marisa Cardoso ${ }^{1 *}$

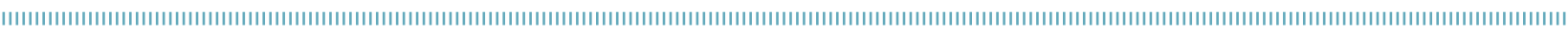

\begin{abstract}
Salami is a ready-to-eat (RTE) product frequently purchased at street fairs in Porto Alegre. Salmonella enterica, Listeria monocytogenes, and coagulase-positive Staphylococcus (CPS) are important causes of foodborne disease and can be transmitted through the consumption of RTE foods. The aim of this study was to evaluate the presence of these pathogens in salami sold at street fairs. Ninety salami samples from three commercial brands available at street fairs were analyzed by routine bacteriological methods for Salmonella spp. and Listeria spp., as well as enumeration of CPS. In addition, two samples from each commercial brand were analyzed for water activity $\left(\mathrm{a}_{\mathrm{w}}\right)$. Samples of brand A showed $\mathrm{a}_{\mathrm{w}}$ values $(0.938$ and $0.942)$ above those set by the legislation, while brand B $(0.849$ and 0.860$)$ and brand $C(0.826$ and 0.854$)$ were compliant. Microbiological analyses showed that $67.7 \%$ were negative to all investigated bacteria. Salmonella Typhimurium was isolated from 4.4\% (4/90) of salami samples, all from commercial brand A. Listeria monocytogenes was detected in 3.3\% (3/90) of samples, from commercial brands B and C. Moreover, 7.7\% (7/90) of samples contained CPS populations non-compliant with legislation. Although the great majority of salami sold at street fairs of Porto Alegre was compliant with standards, S. enterica, L. monocytogenes, and CPS $\geq 5 \times 10^{3} \mathrm{cfu}^{-1} \mathrm{~g}^{-1}$ could be found in this RTE product. Therefore, control measures in the processing industry and consumer's education about foodborne illness prevention should be maintained.
\end{abstract}

KEYWORDS: Pork; ready-to-eat food; coagulase-positive staphylococci.
RESUMO: Salame é um alimento pronto para o consumo frequentemente adquirido pela populaçáo em feiras livres de Porto Alegre. Salmonella enterica, Listeria monocytogenes e Staphylococcus coagulase positiva são importantes causas de doenças transmitidas por alimentos e podem ser veiculadas por alimentos prontos para o consumo. O objetivo desse estudo foi avaliar a presença desses patógenos em salames vendidos em feiras livres. Noventa amostras de salame pertencentes a três marcas comerciais foram analisados por métodos bacteriológicos de rotina quanto à presença de Salmonella spp. e Listeria spp., bem como enumeração de Staphylococcus coagulase positiva (SCP). Além disso, foi determinada a Atividade de Água (aw) de duas amostras de cada marca comercial. Amostras da marca A apresentaram valores de aw $(0,938$ e 0,942$)$ acima do permitido na legislaçáo, enquanto as amostras da marca B $(0,849$ e 0,860$)$ e C $(0,826$ e 0,854$)$ não violaram esse parâmetro. A análise microbiológica demonstrou que $67,7 \%$ das amostras foram negativas para todas as bactérias investigadas. Salmonella Typhimurium foi isolada de 4,4\% (4/90) das amostras de salame, todas da marca comercial A. Listeria monocytogenes foi detectada em 3,3\% (3/90) das amostras das marcas B e C. Além disso, 7,7\% (7/90) das amostras apresentaram SCP acima do número permitido pela legislaçáo. Apesar da grande maioria dos salames comercializados em feiras livres estarem de acordo com a legislação, S. enterica, L. monocytogenes e $\mathrm{SCP} \geq 5 \times 10^{3} \mathrm{cfu}^{-\mathrm{g}^{-1}}$ podem estar presentes nesse alimento pronto para o consumo. Dessa forma, o controle nas indústrias e a educação dos consumidores sobre a prevenção de doenças transmitidas por alimentos devem ser mantidos.

PALAVRAS-CHAVE: Carne suína; produtos prontos para o consumo; estafilococos coagulase positiva.

\footnotetext{
'Universidade Federal do Rio Grande do Sul - Porto Alegre (RS), Brazil

${ }^{2}$ Universidade Federal de Pelotas - Pelotas (RS), Brazil

*Corresponding author: mcardoso@ufrgs.br

Received on: 01/22/2019. Accepted on: 08/02/2019
} 


\section{INTRODUCTION}

Street fairs are considered one of the oldest and most traditional venues for the sale of agricultural products. Although modern life has increased sales in supermarket chains, there is still a substantial portion of the population that prefers to buy farm products at street fairs. In a survey conducted at street fairs in Toledo, Paraná, the profile of consumers was characterized by those $\geq 55$ years of age, those who sort the convenience of the market being close to their home, and those searching for fresh produce, particularly fruits and vegetables (CAZANE et al., 2014). In Porto Alegre, there are 35 street fairs licensed by the municipal authority. The street fairs are set up once a week in different boroughs of Porto Alegre, with fruits, vegetables, and dairy and meat products available for purchase (PORTO ALEGRE, 2019).

Foodborne diseases are an important cause of morbidity worldwide, and the World Health Organization estimates that almost one in 10 people fall ill every year from eating contaminated food (WHO, 2015). Among foods implicated in outbreaks, those that are consumed without cooking (readyto-eat - RTE) have been gaining importance, particularly for transmission of Listeria monocytogenes (EFSA-ECDC, 2017). In Brazil, this pathogen has been reported in several food types, including RTE foods (VALLIM et al., 2015), highlighting the importance of improved monitoring and control measures. In Porto Alegre, the isolation of L. monocytogenes and coagulase-positive Staphylococcus (CPS) from colonial cheese purchased at street fairs has been reported (AUSANI, 2018), raising the concern that other RTE foods sold at these fairs might also be contaminated by pathogens. In particular, Salmonella enterica, which has been frequently reported in pig carcasses in Southern Brazil (SILVA et al., 2012; CORBELLINI et al., 2016), may be present in pork products.

Among RTE meat products, salami is one of the most commonly consumed in the southern region. The designation Salami covers a large number of food products, which differ in ingredients and manufacturing processes. Among these products, "salaminho" is a salami type containing pork or a mixture of pork and beef, stuffed in an edible case with a maximum diameter of $50 \mathrm{~cm}$. It is subjected to fermentation and drying processes; however, heat treatment is not included in its manufacture (BRASIL, 2000). Therefore, food safety will depend on the quality of meat, addition of ingredients with antimicrobial activity, hygiene during production, and reduction of $\mathrm{pH}$ and water activity $\left(\mathrm{a}_{\mathrm{w}}\right)$ during the manufacturing process. Although sausage fermentation and drying duration is not regulated by Brazilian law, the final product must achieve $\mathrm{a}_{\mathrm{w}}$ of 0.90 and $35 \%$ moisture before being considered fit for consumption (BRASIL, 2000). Even so, it has been demonstrated that pathogens, such as L. monocytogenes and S. enterica, when in high concentrations in the ingredients, can survive processing and be present in RTE products
(NIGHTINGALE et al., 2006). Thus, the objective of this study was to investigate the presence of $L$. monocytogenes and S. enterica and to enumerate CPS in salami purchased at street fairs in Porto Alegre.

\section{MATERIAL AND METHODS}

The sample size of salami purchased in street fairs of Porto Alegre was calculated to have a probability of $90 \%$ of finding one sample positive for $S$. enterica, based on an expected prevalence of $2.6 \%$ among "salaminho" (henceforth referred to as salami) (THRUSFIELD, 1986). To achieve representative sampling, the sample units were obtained from street fairs in six boroughs of Porto Alegre (Bom Fim, Cidade Baixa, Jardim São Pedro, Menino Deus, Passo da Mangueira, and Vila Jardim). All purchases took place within a one week interval. At each sampling event, 15 salami samples of the available brands at the sale point were purchased. The collected samples were kept refrigerated until the bacteriological analysis.

From each sample unit, $25 \mathrm{~g}$ were aseptically collected and added to $225 \mathrm{~mL}$ of sterile diluent specific to each microorganism to be analyzed: University of Vermont broth (UVM; BD Difco, Franklin Lakes, NJ) for Listeria spp., 1\% Buffered Peptone Water (BPW; Oxoid, Hampshire, UK) for S. enterica; and $0.1 \%$ Peptone Water (PW; Oxoid, Hampshire, UK) for the enumeration of CPS. All aliquots $(25 \mathrm{~g} / 225 \mathrm{~mL})$ were homogenized individually in a blender (BagMixer, Interscience, Breda, NL) before further analysis.

The detection of $S$. enterica was performed according to ISO 6785/2007 (INTERNATIONAL ORGANIZATION FOR STANDARDIZATION, 2007). Strains confirmed as Salmonella were sent to the Fundação Instituto Oswaldo Cruz (FIOCRUZ), Rio de Janeiro, Brazil, for serotyping. For salami samples containing Salmonella spp., quantification was conducted according to the most probable number (MPN) method using the multiple tube technique (SILVA et al., 2010). Briefly, from the homogenized sample $(25 \mathrm{~g} /$ $225 \mathrm{~mL} \mathrm{1 \%} \mathrm{BPW),} \mathrm{aliquots} \mathrm{of} 10 \mathrm{~mL}$ were distributed into 3 sterile tubes $\left(10^{-1}\right.$ dilution), aliquots of $1 \mathrm{~mL}$ were added to 3 tubes containing $9 \mathrm{~mL}$ of $1 \% \mathrm{BPW}\left(10^{-2}\right.$ dilution), and aliquots of $0.1 \mathrm{~mL}$ were added to three tubes containing $9.9 \mathrm{~mL}$ of $1 \% \mathrm{BPW}\left(10^{-3}\right.$ dilution). After incubation for 24 hours at $35^{\circ} \mathrm{C}, 0.1 \mathrm{~mL}$ from each tube were transferred to $9.9 \mathrm{~mL}$ Rappaport Vassiliadis enrichment broth (RV; Merck, Darmstadt, DE) and incubated for 24 hours at $42^{\circ} \mathrm{C}$. These cultures were then seeded onto xylose-lysine-desoxycholate agar (XLD; Oxoid, Hampshire, UK) and brilliant green agar (BG; Oxoid, Hampshire, UK). After incubation for 24 hours at $35^{\circ} \mathrm{C}$, positive colonies were confirmed by biochemical test and agglutination with polyvalent serum. The number of tubes 
with Salmonella present in each dilution series was used for MPN estimation according to SILVA et al. (2010).

The presence of $L$. monocytogenes was determined according to the method of the United States Department of Agriculture, Food Safety and Inspection Service (USDA/FSIS, 2017), using Listeria agar acc. Ottaviani and Agosti (ALOA; Merck, Darmstadt, DE) as the solid medium for detection. Colonies typical of Listeria spp. were transferred to trypticase soy agar (Oxoid, Hampshire, UK) supplemented with $0.6 \%$ yeast extract (HiMedia, Mumbai, India; TSA-YE) and incubated at $37^{\circ} \mathrm{C}$ for $18-24$ hours. Phenotypic confirmation of suspected colonies was performed by the catalase test, Gram staining, motility, the presence of $\beta$-hemolysis, xylose and rhamnose fermentation and the Christie-Atkins-MunchPetersen (CAMP) test (SILVA et al., 2010).

For the quantification of CPS, serial dilutions $\left(10^{-2}\right.$ and $\left.10^{-3}\right)$ of the initial homogenate $\left(10^{-1}\right)$ were made in $0.85 \%$ $\mathrm{NaCl}$. From each dilution an aliquot of $0.1 \mathrm{~mL}$ was plated on Baird-Parker agar (Oxoid, Hampshire, UK) and suspected CPS colonies were confirmed as described in SILVA et al. (2010). The results were expressed as colony forming units per gram of salami $\left(\mathrm{cfu} \mathrm{g}^{-1}\right)$.

Two units of salami belonging to different batches of each sampled commercial brand were sent to the Universidade do Vale do Taquari, (UNIVATES), Lajeado, Rio Grande do Sul, Brazil, for water activity analysis, following the methodology of the AOAC (2005).

\section{RESULTS}

Ninety salami samples were collected of three commercial brands, A ( $\mathrm{n}=23), B(\mathrm{n}=22)$, and C $(\mathrm{n}=45)$, for sale at six street fairs in Porto Alegre. All samples were produced under sanitary inspection by either federal (brand C) or state authorities (A and B). All sampled salami units were within their designated shelf-life period. The $a_{w}$ for two salami units of each commercial brand were: brand A (0.938 and 0.942$)$, brand B $(0.849$ and 0.860$)$, and brand $\mathrm{C}(0.826$ and 0.854$)$.
Salmonella enterica was isolated from 4.4\% (4/90) salami samples, all belonging to commercial brand A (Table 1). All S. enterica belonged to serovar Typhimurium. The MPN ranged from $<3$ to $3.6 \mathrm{MPN} \mathrm{g}^{-1}$ in the $S$. Typhimurium positive samples. Eight salami samples were positive for $L$. grayi $(\mathrm{n}=4)$, L. monocytogenes $(\mathrm{n}=3)$, and L. innocua $(\mathrm{n}=1)$. None of the salami samples contained more than one Listeria species or concomitant contamination with S. enterica. Listeria monocytogenes was isolated from salami samples belonging to brands $B(\mathrm{n}=2)$ and C $(\mathrm{n}=1)$. CPS was identified in 22 (24.4\%) salami samples; however, only seven (7.7\%) failed to comply with the limits set by the legislation (BRASIL, 2001).

\section{DISCUSSION}

The sampling strategy adopted in this study analysed "salaminho," a specific type of salami available for sale at street fairs in Porto Alegre. The sample profile demonstrated that only a limited number of commercial brands were available, and at five fairs only one commercial brand was sold (data not shown). All salami samples were in compliance with sanitary regulations in having been inspected by the sanitary authority and being offered for sale within their shelf-life period. Both these pieces of information were given on the packaging of the products, representing valuable facts for the consumer at time of purchase. However, other factors related to the food processing also influence the quality and safety of the product. In the salami manufacturing, the duration of the fermentation and drying processes is of great importance with regard to flavour, while diminishing the $\mathrm{pH}$ and $\mathrm{a}_{\mathrm{w}}$ has a positive effect on the elimination of pathogenic bacteria (JAY et al., 2005). Among the three commercial brands analysed in this study, brand A presented with $a_{w}>0.90$, suggesting that the manufacturing process had not been long enough to achieve the standards set by the legislation. In contrast, the other two commercial brands were in compliance with $\mathrm{a}_{\mathrm{w}}$ standards. The non-compliance of salami from some commercial brands has previously been reported (CACCIOPPOLI et al., 2006), suggesting this manufacturing flaw was not uncommon.

Table 1. Results of the microbiological analysis of salami samples collected at six street fairs in Porto Alegre.

\begin{tabular}{lcccc} 
& \multicolumn{3}{c}{ Salami commercial brands } & Total (n=90) \\
\cline { 2 - 4 } Negative to all investigated bacteria & $\mathbf{A}(\mathbf{n = 2 3 )}$ & $\mathbf{B}(\mathbf{n = 2 2 )}$ & $\mathbf{C}(\mathbf{n = 4 5 )}$ & $61(67.7 \%)$ \\
\hline Listeria monocytogenes & $17(73.9 \%)$ & $14(63.6 \%)$ & $30(66.6 \%)$ & $3(3.3 \%)$ \\
\hline Salmonella Typhimurium & $-*$ & $2(9.1 \%)$ & $1(2.2 \%)$ & $4(4.4 \%)$ \\
\hline $\begin{array}{l}\text { Coagulase-positive Staphylococcus } \\
>5 \times 10^{3} \text { cfu.g }{ }^{-1}\end{array}$ & $4(17.4 \%)$ & - & $3(4.4 \%)$ & $7(7.7 \%)$ \\
\hline
\end{tabular}

*all samples were negative. 
Microbiological analysis showed that $67.7 \%$ of samples in the current study were negative for all investigated bacteria; from a minority (4.4\%) though Salmonella Typhimurium was isolated. This serovar in turn is among the most prevalent causing gastroenteritis in humans (FERNANDES et al., 2006; EFSA-ECDC, 2017), and outbreaks related to RTE foods, including salami, have been reported (COWDEN et al., 1989; CDC, 2018; FORD et al., 2018). In Brazil, there are relatively little epidemiological data on Salmonella outbreaks (TAVECHIO et al., 2002; GEIMBA et al., 2004), although this pathogen ranks first in terms of official data (BRASIL, 2016). Notably, S. Typhimurium has been frequently isolated from slaughter pigs, their carcasses, and pork in Brazil (SILVA et al., 2012; CORBELLINI et al., 2016). The presence of $S$. Typhimurium in raw pork intended as an ingredient of fresh sausages has also been reported (CASTAGNA et al., 2004). Moreover, Salmonella contaminated fresh sausages have been identified at the retail level in several studies (SPRICIGO et al., 2008; MÜRMANN et al., 2011; SOUZA et al., 2014). While fresh sausages are cooked before consumption, salami can be eaten without any preparative steps that could inactivate contaminating Salmonella spp. Therefore, the quality of the manufacturing process is crucial for the safety of this product. In our study, $S$. Typhimurium was only isolated from salami samples belonging to commercial brand $A$, in which the $\mathrm{a}_{\mathrm{w}}$ was not in compliance with standards (BRASIL, 2000). Although the sample units sent for $\mathrm{a}_{\mathrm{w}}$ analysis were not the same subjected to microbiological investigation, the similar results obtained from different salami units suggested that there might have been an inherent problem with shorter drying times for brand A. Although Salmonella has been shown to survive in low-moisture food (JIN et al., 2018), $\mathrm{a}_{\mathrm{w}}$ values around 0.96 seem to be needed for its growth, and $\mathrm{a}_{\mathrm{w}}$ values $<0.94$ inhibit its growth (JAY et al., 2005). In this regard, a reduction of ripening time was identified as the main risk factor in a $S$. Typhimurium outbreak associated with salami consumption in Northern Italy (PONTELLO et al., 1998). The hazard poised by a given food to consumers is related to the population of pathogens in the food, thus information about the number of Salmonella is important for the conduction of a future risk assessment. Therefore, besides the Salmonella qualitative investigation its quantification in positive samples was conducted. As reported in fresh pork sausage (SPRICIGO et al., 2008; MÜRMANN et al., 2011), the number of viable $S$. Typhimurium ( $<3$ to $3.6 \mathrm{NMP} \mathrm{g}^{-1}$ ) was much below the estimated infective dose $\left(10^{4} \mathrm{cfu}\right)$ for this serovar (BOLLAERTS et al., 2008); however, the infective dose for humans may be influenced by the susceptibility of host and Salmonella strain, and can be as low as $10^{1}$ cfu for less resistant consumers (VOUGHT; TATINI, 1998).

The occurrence of $L$. monocytogenes is less affected by $a_{w}$, since this pathogen is recognized to grow at $a_{w}$ values of 0.93 (JAY et al., 2005). Listeria monocytogenes is not included among the microbiological standards for salami (BRASIL, 2001); therefore, contaminated samples could not be considered non-compliant. The enumeration of L. monocytogenes in positive samples was not performed in this study, which could have contributed to show the actual hazard of the positive salami samples for the exposed consumers. Although the current legislation (BRASIL, 2001) does not include the enumeration of $L$. monocytogenes in positive food samples, it is known that a low dose $(<100 \mathrm{cfu})$ of $L$. monocytogenes is a hazard only for susceptible groups, such as pregnant women and the elderly. However, in these groups listeriosis is a serious disease and may result in hospitalization and death (VÁZQUEZ-BOLAND et al., 2001). Therefore, even the isolation of $L$. monocytogenes may still pose a risk for consumers of street fairs. Considering the way salami is served in southern Brazil, such as in sandwiches and other cold dishes, it can be assumed that consumers may be exposed to potential infection, especially those more susceptible. The association of strains of $L$. monocytogenes resistant to environmental conditions, its wide dissemination in animal sources and its ability to form biofilms are serious problems for the food industry (VALLIM et al., 2015). Since eradication of $L$. monocytogenes in foods and the processing environment is difficult, it is important to promote strong microbiological surveillance and monitoring of food processing. In addition, information should be provided for consumers regarding listeriosis, particularly among the more susceptible groups.

Taking into account the bacteria investigated in this study, besides the four salami samples positive for Salmonella, seven other samples were non-compliant with the legislation regarding the limit of CPS $\leq 5 \times 10^{3} \mathrm{cfu} \mathrm{g}^{-1}$ (BRASIL, 2001). Staphylococcus aureus is the most important CPS involved in food poisoning outbreaks, and is frequently introduced into food due to poor hygiene during handling (SILVA et al., 2010). Enterotoxin is produced by $S$. aureus when it grows on food and this cannot be reliably inactivated by cooking (LE LOIR et al., 2003). Although estimation of staphylococcal food poisoning risk is commonly based on the S. aureus population present in the food, the evaluation of enterotoxin expression in the food matrix has been gaining prominence (SCHELIN et al., 2017). For instance, the production of staphylococcal enterotoxin A (SEA) under foodrelated stress conditions present in processed pork products, demonstrated that toxin levels sufficient to cause food poisoning were achieved one day after inoculation of $10^{7} \mathrm{cfu}$ of S. aureus (WALLIN-CARLQUIST et al., 2010). Moreover, levels of SEA were obtained in boiled and smoked hams, and it was not detected in salami. Therefore, variation in $S$. aureus growth behavior and enterotoxin production must be taken into account by food processors in tailoring and evaluating the manufacturing process of specific products to maximize food safety (SCHELIN et al., 2017). 


\section{CONCLUSIONS}

Although the great majority of salami sold at street fairs in Porto Alegre is in compliance with the legislation, $S$. Typhimurium and L. monocytogenes and CPS $\geq 5 \times 10^{3}$ cfu. $\mathrm{g}^{-1}$ could be found in this RTE product. Therefore, control measures in the processing industry and consumer's education about foodborne illness prevention should be maintained.

\section{ACKNOWLEDGMENTS}

This study was carried out with the support of the Coordination of Improvement of Higher Education Personnel (CAPES) — Financing Code 001 (Programa Nacional de Pós-Doutorado [PNPD] scholarship for L. Haubert and PhD scholarships for G.O. Werlang and C.M. Peter).

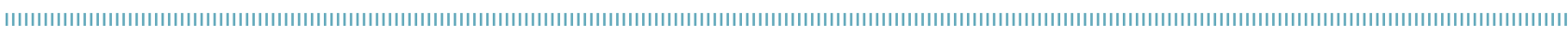
REFERENCES

ASSOCIATION OF OFFICIAL ANALYTICAL CHEMISTS (AOAC). Official Methods of Analysis of AOAC International. Method 978.18. 18. ed. Gaithersburg: AOAC International, 2005. Chap. 42.

AUSANI, T.C. Qualidade microbiológica de queijos coloniais sob inspeção higiênico-sanitária comercializados em Porto Alegre. 2018. 180p. Tese (Doutorado em Ciências Veterinárias) Faculdade de Veterinária Universidade Federal do Rio Grande do Sul, Porto Alegre, 2018. Available from: <https://www.lume. ufrgs.br/bitstream/handle/10183/181013/001072997. pdf? sequence $=1$ \&isAllowed $=\mathrm{y}>$. Access on: Jan. 142019 .

BOLLAERTS, K.; AERTS, M.; FAES, C.; GRIJSPEERDT, K.; DEWULF, J.; MINTIENS, K. Human salmonellosis: estimation of dose-illness from outbreak data. Risk Analysis, Hoboken, v.28, n.2, p.427-440, 2008. https://doi.org/10.1111/j.1539-6924.2008.01038.x

BRASIL. agência Nacional de Vigilância Sanitária. Resolução $R D C n^{\circ} 12$, de 2 de janeiro de 2001. Regulamento técnico sobre padrões microbiológicos para alimentos. Brasília, DF: ANVISA, 2001. Available from: <http://portal.anvisa.gov.br/ documents/33880/2568070/RDC_12_2001.pdf/15ffddf63767-4527-bfac-740aO400829b> Access on: Jan. 62017.

BRASIL. Ministério da Agricultura e do Abastecimento. Instrução Normativa n.22, de 31 de julho de 2000. Available from: <http:// extranet.agricultura.gov.br/sislegis-consulta/consultarLegislacao. do?operacao=visualizar\&id=2239> . Access on: Jan. 142019.

BRASIL. Ministério da Saúde. Surtos de Doenças Transmitidas por Alimentos no Brasil. 2016. Available from: <http://portalarquivos. saude.gov.br/images/pdf/2016/junho/08/Apresenta-----oSurtos-DTA-2016.pdf>. Access on: Jan. 142019.

CACCIOPPOLI, J.; CUSTÓDIO, F.B.; VIEIRA, S.M.; COELHO, J.V.; GLÓRIA, M.B.A. Aminas bioativas e características físico-químicas de salames tipo italiano. Arquivo Brasileiro de Medicina Veterinária e Zootecnia, Belo Horizonte, v.58, n.4, p.648-657, 2006. http:// dx.doi.org/10.1590/S0102-09352006000400029

CASTAGNA, S.M.F.; SCHWARZ, P.; CANAL, C.W.; CARDOSO, M. Prevalência de suínos portadores de Salmonella sp. ao abate e contaminação de embutidos tipo frescal. Acta Scientiae Veterinariae, Porto Alegre, v.3, n.2, p.141-147, 2004. https:// doi.org/10.22456/1679-9216.16836

CAZANE, A.L.; MACHADO, J.G.C.F.; SAMPAIO, F.F. Análise de feiras livres como alternativa de distribuição de frutas, legumes e verduras (FLV). Informe Gepec, Toledo, v. 18, n. 1, p.119-137, 2014.
CENTER FOR DISEASE CONTROL (CDC). Foodborne outbreaks. 2018. Available from: <https://www.cdc.gov/foodsafety/ outbreaks/index.html>. Access on: Jan. 142019.

CORBELLINI, L.G.; BIANCO JÚNIOR, A.; COSTA, E.F.; DUARTE, A.S.R.; ALBUQUERQUE, E.R.; KICH, J.D.; CARDOSO, M.; NAUTA, M. Effect of slaughterhouse and day of sample on the probability of a pig carcass being Salmonella-positive according to the Enterobacteriaceae count in the largest Brazilian pork production region. International Journal of Food Microbiology, Amsterdam, v.228, p.58-66, 2016. https://doi.org/10.1016/j. ijfoodmicro.2016.03.030

COWDEN, J.M.; O'MAHONY, M.; BARTLETT, C.L.R.; RANA, B.; SMYTH, B.; LYNCH, D.; TILLET, H. WARD, L.; ROBERTS, D.; GILBERT, R.J.; BAIRD-PARKER, A.C.; KILSBY, D.C. A national outbreak of Salmonella typhimurium DT 124 caused by contaminated salami sticks. Epidemiology and Infection, Cambridge, v. 103, n.2, p.219225, 1989. https://doi.org/10.1017/S0950268800030569

EUROPEAN FOOD SAFETY AUTHORITY, EUROPEAN CENTRE FOR DISEASE PREVENTION AND CONTROL (EFSA-ECDC). The European Union summary report on trends and sources of zoonoses, zoonotic agents and food-borne outbreaks in 2016. EFSA Journal, Parma, v. 15, n. 12, p.5077-5305, 2017. http:// dx.doi.org/10.2903/j.efsa.2018.5500

FERNANDES, S.A.; TAVECHIO, A.T.; GHILARDI, A.C.R.; DIAS, A.M.G.; ALMEIDA, I.A.Z.C.; MELO, L.C.V. Salmonella serovars isolated from humans in São Paulo State, Brazil, 1996-2003. Revista do Instituto de Medicina Tropical São Paulo, São Paulo, v.48, n.4, p.179-184, 2006. http://dx.doi.org/10.1590/ S0036-46652006000400001

FORD, L.; MOFFATT, C.R.M.; FEARNLEY, E.; MILLER, M.; GREGORY, J.; SLOAN-GARDNER, T.S.; POLKINGHORNE, B.G.; BELL, R.; FRANKLIN, N.; WILLIAMSON, D.A.; GLASS, K.; KIRK, M.D. The epidemiology of Salmonella enterica outbreaks in Australia, 20012016. Frontiers in Sustainable Food Systems, v.2, n.86, 2018. Available from: <https://www.frontiersin.org/articles/10.3389/ fsufs.2018.00086/full>. Access on: Jan. 14 2019. https:// doi.org/10.3389/fsufs.2018.00086

GEIMBA, M.P.; TONDO, E.C..; DE OLIVEIRA, F.A.; CANAL, C.W.; BRANDELLI, A. Serological characterization and prevalence of $s p v R$ genes in Salmonella isolated from foods involved in outbreaks in Brazil. Journal of Food Protection, Des Moines, v.67, n.6, p.1229-1233, 2004. https://doi. org/10.4315/0362-028x-67.6.1229 
INTERNATIONAL ORGANIZATION FOR STANDARDIZATION (ISO). ISO 6579. Microbiology of food and animal feeding stuffs - Horizontal method for the detection of Salmonella spp. 4. ed. Geneva: ISO, 2007. 27p. (Amendment 1:15/07/2007).

JAY, J.M.; LOESSNER, M.J.; GOLDEN, D.A. Modern Food Microbiology. New York: Springer, 2005. 789p.

JIN, Y.; PICKENS, S.R.; HILDEBRANDT, I.M.; BURBICK, S.J.; GRASSOKELLEY, E.M.; KELLER, S.E.; ANDERSON, N.M. Thermal inactivation of Salmonella Agona in low-water activity foods: predictive models for the combined effect of temperature, water activity, and food component. Journal of Food Protection, Des Moines, v.81, n.9, p.14111417, 2018. https://doi.org/10.4315/0362-028X.JFP-18-041

LE LOIR, Y.; BARON, F.; GAUTIER, M. Staphylococcus aureus and food poisoning. Genetics and Molecular Research, Ribeirão Preto, v.2, n. 1, p.63-76, 2003.

MÜRMANN, L.; CORBELLINI, L.G.; COLLOR, A.A.; CARDOSO, M. Quantitative risk assessment for human salmonellosis through the consumption of pork sausage in Porto Alegre, Brazil. Journal of Food Protection, Des Moines, v.74, n.4, p.553-558, 2011. https://doi.org/10.4315/0362-028X.JFP-10-339

NIGHTINGALE, K.K.; THIPPAREDDI, H.; PHEBUS, R.K.; MARSDEN, J.L.; NUTSCH, A.L. Validation of a traditional Italian-style salami manufacturing process for control of Salmonella and Listeria monocytogenes. Journal of Food Protection, Des Moines, v.69, n.4, p.794-800, 2006. https://doi.org/10.4315/0362-028x-69.4.794

PONTELLO, M.; SOLDANO, L.; NASTASI, A.; MAMMINA, C.; ASTUTI, M.; DOMENICHINI, M.; BELLUZI, G.; SOCCINI, E.; SILVESTRI, M.G.; GATTI, M.; GEROSA, E.; MONTAGNA, A. A community-based outbreak of Salmonella enterica serotype Typhimurium associated with salami consumption in Northern Italy. Epidemiology and Infection, Cambridge, v.120, n.3, p.209-214, 1998. https:// doi.org/10.1017/s095026889800870x

PORTO ALEGRE. Feiras Modelo. 2019. Available from: <http:// www2.portoalegre.rs.gov.br/smic/default.php?p_secao=204>. Accessed on: Jan. 142019.

SCHELIN, J.; SUSILO, Y.B.; JOHLER, S. Expression of staphylococcal enterotoxins under stress encountered during food production and preservation. Toxins (Basel), v.9, n.12, p.401-410, 2017. https://doi.org/10.3390/toxins9120401

SILVA, L.E., DIAS, V.; FERRONATTO, A., GUERRA, P.; BERNO, L.; TRICHES, N., KICH, J.D.; CORBELLINI, L.G.; CARDOSO, M. Longitudinal dissemination of Salmonella enterica clonal groups through the slaughter process of Salmonella-positive pig batches. Journal of Food Protection, Des Moines, v.75, n.9, p. 1580-1588, 2012. https://doi.org/10.4315/0362-028X.JFP-11-515

SILVA, N.; JUNQUEIRA, V.C.A.; SILVEIRA, N.F.A.; TANIWAKI, M.H.; SANTOS, R.F.S.; GOMES, R.A.R. Manual de métodos de análises microbiológicas de alimentos e água. 4. ed. São Paulo: Livraria Varela, 2010. 624p.

SOUZA, M.; PINTO, F.G.S.; BONA, E.A.M.; MOURA, A.C. Qualidade higiênico-sanitária e prevalência de sorovares de Salmonella em linguiças frescais produzidas artesanalmente e inspecionadas, comercializadas no oeste do Paraná, Brasil. Arquivos do Instituto Biológico, São Paulo, v.81, n.2, p.107-1 12, 2014. http://dx.doi. org/10.1590/1808-1657000772012

SPRICIGO, D.A.; MATSUMOTO, S.R.; ESPÍNDOLA, M.L.; FERRAZ, S.M. Prevalência, quantificação e resistência a antimicrobianos de sorovares de Salmonella isolados de lingüiça frescal suína. Ciência e Tecnologia de Alimentos, Campinas, v.28, n.4, p.779-785, 2008. http://dx.doi.org/10.1590/SO101-20612008000400003

TAVECHIO, A.T.; GHILARDI, A.C.R.; PERESI, J.T.M.; FUZIHARA, T.O.; YONAMINE, E.K.; JAKABI, M.; FERNANDES, S.A. Salmonella serotypes isolated fromnonhuman sources in São Paulo, Brazil, from 1996 through 2000. Journal of Food Protection, Des Moines, v.65, n.6, p.10411044, 2002. https://doi.org/10.4315/0362-028X-65.6.1041

THRUSFIELD, M. Veterinary Epidemiology. London: Butterworth, 1986. 280p.

UNITED STATES DEPARTMENT OF AGRICULTURE/FOOD SAFETY AND INSPECTION SERVICE (USDA/FSIS). Isolation and identification of Listeria monocytogenes from red meat, poultry, ready-to-eat siluriformes (fish) and egg products and environmental samples. In: UNITED STATES DEPARTMENT OF AGRICULTURE/FOOD SAFETY AND INSPECTION SERVICE (USDA/ FSIS). Microbiology Laboratory Guidebook. Athens: United States Department of Agriculture/Food Safety and Inspection Service, 2017. Chap. 8.10. Available from: <https://www.fsis.usda.gov/ wps/portal/fsis/topics/science/laboratories-and-procedures/ guidebooks-and-methods/microbiology-laboratory-guidebook/ microbiology-laboratory-guidebook>. Access on: Mar. 52018.

VALLIM, D.C.; HOFER, C.B.; LISBÔA, R.C.; BARBOSA, A.V.; RUSAK, L.A.; REIS, C.M.F.; HOFER, E. Twenty years of Listeria in Brazil: Occurrence of Listeria species and Listeria monocytogenes serovars in food samples in Brazil between 1990 and 2012. BioMed Research International, Cairo, v.2015, article ID 540204, 2015. http://dx.doi.org/10.1155/2015/540204

VÁZQUEZ-BOLAND, J.A.; KUHN, M.; BERCHE, P.; CHAKRABORTY, T.; DOMÍNGUEZ-BERNAL, G.; GOEBEL, W.; GONZÁLEZ-ZORN, B.; WEHLAND, J.; KREFT, J. Listeria pathogenesis and molecular virulence determinants. Clinical Microbiology Reviews, Washington, v.14, n.3, p.584-640, 2001 . https://doi.org/10.1128/ CMR. 14.3.584-640.2001

VOUGHT, K.J.; TATINI, S.R. Salmonella enteritidis contamination of ice cream associated with a 1994 multistate outbreak. Journal of Food Protection, Des Moines, v.61, n.1, p.5-10, 1998. https:// doi.org/10.4315/0362-028x-61.1.5

WALLIN-CARLQUIST, N.; MÁRTA, D.; BORCH, E.; RÅDSTRÖM, P. Prolonged expression and production of Staphylococcus aureus enterotoxin A in processed pork meat. International Journal of Food Microbiology, Amsterdam, v.141, Suppl.1, p.S69-S74, 2010. https://doi.org/10.1016/j.ijfoodmicro.2010.03.028

WORLD HEALTH ORGANIZATION (WHO). WHO estimates of the global burden of foodborne diseases. Geneva: WHO Press, 2015. 268p. 